\title{
Fruit quality of Granny Smith apples picked at different harvest times and treated with 1-MCP
}

\author{
Nenad MAGAZIN, Dušan Gvozdenović, Zoran KeSERović, Biserka MiLić
}

Fac. Agric. Novi Sad, Dep. fruitgrowing, viticulture, horticulture and landscape architecture, Trg Dositeja Obradovića 8, 21000 Novi Sad, Serbia

nmagazin@polj.uns.ac.rs

* Correspondence and reprints

Fruits, 2010, vol. 65, p. 191-197 (C) 2010 Cirad/EDP Sciences All rights reserved DOI: $10.1051 /$ fruits/2010013 www.fruits-journal.org

RESUMEN ESPAÑOL, p. 197

\section{Fruit quality of Granny Smith apples picked at different harvest times and treated with 1-MCP.}

Abstract - Introduction. Superficial scald is one of the most economically serious postharvest disorders of apples. The optimal harvest window and 1-MCP treatment significantly diminish the risk of storage scald and retain quality of apples stored in a normal atmosphere. Materials and methods. Fruits from three different harvest dates (23rd and 30th September, and 7th October 2008) were treated with 1-MCP (SmartFresh $\left.{ }^{\mathrm{TM}}\right)$ immediately after harvest, and stored in a normal atmosphere $(1 \pm 0.5)^{\circ} \mathrm{C}$ for 180 days followed by a shelf-life period of 7 days at $(21 \pm 1)^{\circ} \mathrm{C}$. Assessments of superficial scald severity, firmness, total soluble solids and titratable acidity were recorded at days 1 and 7 after storage. Organoleptic quality assessments were made after the shelf-life period. Results. 1-MCP treatment was able to control superficial scald before and after shelf life in fruits from the last two harvest times. The highest scald values during shelf life were observed in untreated and 1-MCP-treated fruits from the earliest harvest (3.6 and 2.3, respectively). 1-MCP and early harvest time were determined to have a positive effect on retention of firmness and titratable acidity during storage. Total soluble solids was not affected by 1-MCP treatment. Combination of 1-MCP treatment and mid- or late harvest time gave the best evaluation scores for organoleptic quality. Conclusion. Our results show that 1-MCP treatments of late-harvested "Granny Smith" apples could offer satisfactory results for long-term air storage considering both the absence of superficial scald and retention of fruit quality.

Serbia / Malus (fruits) / controlled atmosphere storage / postharvest decay / scald / timing / harvesting date / keeping quality

\section{Qualité des pommes Granny Smith récoltées à différentes dates et traitées au 1-MCP.}

Résumé - Introduction. D'un point de vue économique, l'échaudure superficielle constitue l'un des facteurs de dépréciation les plus graves pour les pommes récoltées. Le choix d'une période optimale de récolte et l'application d'un traitement au 1-MCP permettent de réduire sensiblement le risque d'apparition de cette échaudure et de conserver la qualité des pommes stockées en atmosphère normale. Matériel et méthodes. Des fruits récoltés à trois dates différentes (23 et 30 septembre et 7 octobre 2008) ont été traités au 1-MCP $\left(\right.$ SmartFresh $\left.^{\mathrm{TM}}\right)$ immédiatement après récolte, stockés en atmosphère normale à $(1 \pm 0,5)^{\circ} \mathrm{C}$ pendant 180 jours puis laissés pendant 7 jours à $(21 \pm 1)^{\circ} \mathrm{C}$. Des évaluations de la gravité de l'échaudure superficielle, de la fermeté des fruits, de leur teneur totale en solides solubles et de leur acidité titrable ont été effectuées aux jours 1 et 7 après stockage. Des évaluations de leur qualité organoleptique ont été faites en fin de période de conservation. Résultats. Le traitement au 1-MCP a permis de contrôler l'échaudure superficielle avant et après la période de 7 jours à $(21 \pm 1)^{\circ} \mathrm{C}$ pour les fruits récoltés aux deux dernières dates. Pendant cette période, l'échaudure a été la plus marquée pour les fruits de la première récolte, qu'ils aient été ou non traités au 1-MCP (scores de 3,6 et 2,3, respectivement). L'application de 1-MCP et une récolte précoce ont eu un effet positif sur le maintien de la fermeté et de la teneur en acidité titrable pendant le stockage. La teneur totale en solides solubles n'a pas été affectée par le traitement au 1-MCP. La combinaison d'un traitement au 1-MCP et d'une récolte à mi- ou en fin de saison ont donné les meilleurs scores d'évaluation de la qualité organoleptique des pommes stockées. Conclusion. Nos résultats montrent que les traitements au 1-MCP appliqués aux dernières dates de récolte pourraient donner des résultats satisfaisants pour le stockage à l'air, à long terme, des pommes "Granny Smith" du fait à la fois de l'absence d'échaudure superficielle et du maintien de la qualité des fruits.

Serbie / Malus (fruits) / stockage en atmosphère contrôlée / maladie postrécolte / échaudure / choix de la date / date de récolte / aptitude à la conservation 


\section{Introduction}

Superficial scald is one of the most economically serious postharvest disorders of apples $^{1}$. The disorder manifests as skin browning which develops on any part of the skin, not affecting the flesh. Superficial scald usually appears during shelf life of fruits removed from cold storage, but with highly susceptible cultivars the scald can appear even during storage [1]. Scald has been associated with oxidation of $\alpha$-farnesene and the consequent accumulation of conjugated trienes [2].

The maturity stage at harvest may predispose fruits to some disorders [3]. Less mature fruits develop superficial scald more easily [4] and do not develop typical full flavour [5]. Fruits that are picked too late are much less prone to superficial scald, but soften and become mealy prior to marketing [6]. Choosing an optimal harvest window can significantly diminish the risk of storage scald and upgrade storage potential.

Application of the gaseous compound 1-methylcyclopropene (1-MCP) has been reported to have an inhibiting effect on superficial scald development [1, 7-9]. 1-MCP postharvest treatment primarily prevents ethylene from binding to receptors and thus reducing ethylene sensitivity and respiration. Treated apples stored in air maintain important quality characteristics such as fruit firmness and high total acids. At the same time, as ethylene plays an important role in production of aroma volatiles, 1-MCP-treated fruits can lack aroma, which is an important organoleptic quality trait $[10,11]$. It has also been suggested that 1-MCP treatment of certain air-stored cultivars can replace controlled atmosphere storage $[12,13]$.

The objective of our study was to investigate the combined effects of harvest time and 1-MCP treatment on superficial scald development and quality of air-stored Granny Smith apples.

\footnotetext{
${ }^{1}$ Kupferman E., Storage scald of apples, 2001, http://postharvest.tfrec.wsu.edu/ EMK2000C.pdf
}

\section{Materials and methods}

\subsection{Fruit source}

Apples were harvested in 2008 from 8-yearold Granny Smith trees grafted on M-9 EMLA rootstocks in the experimental orchard of the Department of Fruit Growing and Viticulture, Faculty of Agriculture, Novi Sad, Serbia. Fruits were harvested on 23rd September (harvest 1), 30th September (harvest 2 - commercial harvest date) and 7th October (harvest 3). After each harvest, we used 240 fruits of uniform size and without external defects to form eight replicates of 30 fruits. An additional 20 fruits were used to assess maturity indices (table I). Lack of differences between starch maturity indices of fruits picked at different times were probably due to subjective interpretation, as suggested by Piers et al. [14].

\subsection{1-MCP treatment}

Within $2 \mathrm{~h}$ after harvest, four replicates of 30 fruits were treated with 1-MCP (Smart Fresh ${ }^{\mathrm{TM}} 0.14 \%$ Technology, Rohm and Haas Company) in a gas-tight 120-L plastic container. 1-MCP was weighed into a small jar to obtain a final gas concentration of $0.625 \mu \mathrm{L} \cdot \mathrm{L}^{-1}$ and was dissolved in pure water $\left(20^{\circ} \mathrm{C}\right)$. The jar was shaken and placed into an airtight container. A small battery-propelled ventilator was attached to the jar in order to obtain better distribution of 1-MCP gas in the container. Control fruits were kept in a similar plastic container without any treatment. After $24 \mathrm{~h}$ at $20^{\circ} \mathrm{C}$, the plastic containers were opened and fruits were stored in cold storage.

\subsection{Fruit storage and sampling}

All replicate fruits were placed in separate wooden bins and were stored in regular atmosphere cold storage $\left[(1 \pm 0.5){ }^{\circ} \mathrm{C},(90 \pm\right.$ $\left.5) \% \mathrm{RH},\left(0.03 \% \mathrm{CO}_{2}+21 \% \mathrm{O}_{2}\right)\right]$ for 180 days followed by a shelf-life period of 7 days at a normal atmosphere of $(21 \pm 1){ }^{\circ} \mathrm{C}$ and $(60 \pm 5) \% \mathrm{RH}$. Immediately after storage, 15 fruits of each replicate were assessed at day 1 and at day 7 . 
Table I.

Maturity indices of Granny Smith apples harvested on three different dates (Serbia, 2008, means of 20 fruits \pm standard deviation).

\begin{tabular}{lccccc}
\hline Harvest date & $\begin{array}{c}\text { Firmness } \\
\left(\mathrm{kg} \cdot \mathrm{cm}^{-2}\right)\end{array}$ & $\begin{array}{c}\text { Starch index } \\
(1-10)\end{array}$ & $\begin{array}{c}\text { Total soluble solids } \\
(\%)\end{array}$ & $\begin{array}{c}\text { Titratable acidity } \\
\text { (\% of malic acid) }\end{array}$ & $\begin{array}{c}\text { Streif's maturity index } \\
\text { 23 September }\end{array}$ \\
$\begin{array}{l}9.57 \pm 0.85 \\
\text { 30 September }\end{array}$ & $6.4 \pm 1.60$ & $12.82 \pm 1.20$ & 1.10 & 0.12 \\
$\begin{array}{l}\text { (commercial harvest date) } \\
\text { 07 October }\end{array}$ & $8.89 \pm 0.72$ & $6.2 \pm 1.24$ & $12.88 \pm 0.97$ & 0.97 & 0.11 \\
\end{tabular}

\subsection{Assessments}

The starch index was evaluated using the starch iodine test (Code Amidon, Ctifl, 2002). Firmness of fruit flesh was measured using a FT 327 penetrometer (Winopal Forshchungsbedarf GmbH, Ahnsbeck, Germany) with an 11-mm probe. Two measurements were made on opposite sides of each fruit.

Total soluble solids (TSS) were determined using a hand refractometer (0-32\%). Streif's Maturity Index was calculated using the formula: Streif's Maturity Index $=[$ Firmness / (Starch Index $\times$ TSS)]. Titratable acidity (TA) was measured by titration with $0.1 \mathrm{~N}$ $\mathrm{NaOH}$ to $\mathrm{pH}$ 8.1. Results were expressed as percentage of malic acid in fruits. Intensity of scald was visually estimated according to the percentage of scalded surface with a scale from 0 to 4 , where $0=$ no surface area affected, $1=<10 \%, 2=10-25 \%, 3=25$ $50 \%, 4=>50 \%$ of the surface area affected [15]. Evaluations of overall external appearance, juiciness, mealiness, taste and aroma were conducted by five academic panellists after shelf life. Scores were: bad (1-3), good (4-6) and very good (7-9).

\subsection{Statistical analyses}

A randomised plot two-factorial experimental design with four replicates of 15 fruits per replicate was used. The data were analysed using analysis of variance (ANOVA) and the means were compared using Fisher's least significant difference (LSD) test $(P<0.05)$ with STATISTICA 8 (StatSoft Inc., Tulsa, USA).

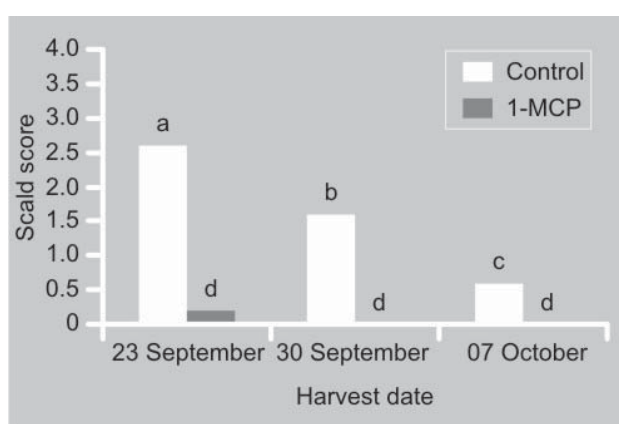

Figure 1.

Severity of superficial scald (1-4 scale) in Granny Smith apples treated with $1-\mathrm{MCP}$ and stored for 180 days at $1{ }^{\circ} \mathrm{C}$ $(90 \% \mathrm{RH})$ in air. Means with different letters are significantly different (Fisher's LSD, $P=0.05$ )

\section{Results and discussion}

\subsection{Scald score}

The apple scald severity on day 1 after storage was high for untreated apples from harvests 1 and 2 (figure 1). Slight superficial scald was determined in untreated apples from harvest 3, but only 1-MCP-treated apples, regardless of harvest time, showed no or very slight symptoms. Similarly, 1-MCP treatment was able to prevent scald development on Granny Smith apples stored in air for 3 months and 6 months [16]. Harvest delay can reduce superficial scald [17] but it cannot completely control it, especially during a long storage period [18].

After the shelf-life period, only 1-MCPtreated apples from harvests 2 and 3 had no scald (figure 2), which could be interesting for air-stored late-harvest apples [11]. Untreated apples from all three harvests had high ratios of superficial scald (figure 2). A similar situation occurred with 1-MCP-treated fruits from harvest 1 , which 


\section{N. Magazin et al.}

Figure 2.

Severity of superficial scald (14 scale) in Granny Smith apples treated with 1-MCP and stored for 180 days at $1^{\circ} \mathrm{C}(90 \% \mathrm{RH})$ in air +7 days at $21^{\circ} \mathrm{C}(60 \% \mathrm{RH})$. Means with different letters are significantly different (Fisher's LSD, $P=0.05$ ).

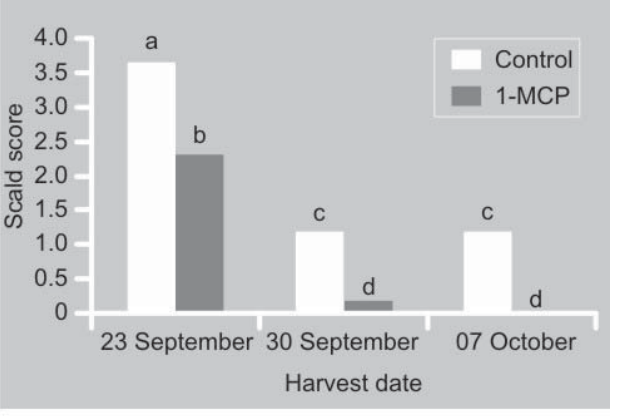

corresponds with the results of Akbudak et al. who found that apples picked at optimum maturity for long-term controlledatmosphere storage stored under normal atmosphere conditions, with or without 1MCP, during shelf life showed a significant increase in severity of superficial scald [19].

\subsection{Fruit quality}

Firmness is a major factor in consumer preferences [20]. After storage, 1-MCP-treated fruits picked on 23rd September, 23th September and 7 th October remained firmer than untreated fruits at day 1 (table II). Data also shows the positive effect of early harvest times on firmness values during storage $[10,21]$. The lowest firmness value was obtained from untreated harvest 3 fruits, which corresponds with the lowest firmness at harvest time (table I).
Similar results were observed during shelf life. 1-MCP was determined to have a positive effect during shelf life on retention of firmness, as has been shown in previous studies [8, 11, 19, 22]. Even late-harvest apples treated with 1-MCP remained much firmer during shelf life than those untreated, regardless of their harvest time.

\subsection{Total soluble solids}

After the storage period, the only significant difference observed for the Granny Smith total soluble solids content was noticed between 1-MCP-treated and untreated fruits from harvest 3 , probably due to higher respiration rates of late-harvested untreated fruits (table II). Similar studies [8, 19, 22] also found that 1-MCP treatment was ineffective on the changes in apple total soluble solids.

\subsection{Titratable acidity}

The treatments with 1-MCP maintained the titratable acidity values after storage at higher levels compared with untreated fruits (table II), which has not always been observed in previous studies $[8,23]$. The effect of harvest time was also noticed, as untreated fruits harvested on 7th October had the lowest titratable acidity, which is an indicator of advanced maturity [6]. The effectiveness of 1-MCP was lost during shelf life.

Table II.

Effect of 1-MCP applied at the time of fruit harvest and of three different harvest dates on quality parameters of Granny Smith apples stored at $1^{\circ} \mathrm{C}$ for 6 months followed by a shelf-life period of 7 days at $(21 \pm 1)^{\circ} \mathrm{C}$ (Serbia, 2009).

\begin{tabular}{|c|c|c|c|c|c|c|c|}
\hline \multirow[t]{2}{*}{ Harvest date } & \multirow[t]{2}{*}{ Treatment } & \multicolumn{2}{|c|}{$\begin{array}{l}\text { Firmness } \\
\left(\mathrm{kg} \cdot \mathrm{cm}^{-2}\right)\end{array}$} & \multicolumn{2}{|c|}{$\begin{array}{l}\text { Total soluble solids } \\
\text { (\%) }\end{array}$} & \multicolumn{2}{|c|}{$\begin{array}{l}\text { Titratable acidity } \\
\text { (\% of malic acid) }\end{array}$} \\
\hline & & Day 1 & Day 7 & Day 1 & Day 7 & Day 1 & Day 7 \\
\hline \multirow[t]{2}{*}{23 September } & Control & $6.53 c$ & $5.89 \mathrm{c}$ & $14.40 \mathrm{ab}$ & $14.22 \mathrm{a}$ & $5.91 \mathrm{ab}$ & $4.79 \mathrm{a}$ \\
\hline & 1-MCP & $8.51 \mathrm{a}$ & $7.82 \mathrm{a}$ & $14.40 \mathrm{ab}$ & $13.94 a b$ & $6.38 \mathrm{a}$ & $4.93 \mathrm{a}$ \\
\hline \multirow{2}{*}{$\begin{array}{l}30 \text { September } \\
\text { (commercial harvest date) }\end{array}$} & Control & $6.99 \mathrm{~b}$ & $5.97 \mathrm{c}$ & $14.39 \mathrm{ab}$ & $14.16 \mathrm{a}$ & $5.67 \mathrm{ab}$ & $4.59 \mathrm{a}$ \\
\hline & 1-MCP & $8.39 a$ & $7.93 \mathrm{a}$ & $14.19 a b$ & $14.11 \mathrm{a}$ & $6.30 \mathrm{a}$ & $4.93 \mathrm{a}$ \\
\hline \multirow[t]{2}{*}{07 October } & Control & $5.37 \mathrm{~d}$ & $4.44 \mathrm{~d}$ & $13.88 \mathrm{~b}$ & $13.59 \mathrm{~b}$ & $5.38 \mathrm{~b}$ & $4.99 \mathrm{a}$ \\
\hline & 1-MCP & $7.07 \mathrm{~b}$ & $6.67 \mathrm{~b}$ & $14.55 \mathrm{a}$ & $13.81 \mathrm{ab}$ & $6.25 a$ & $4.50 \mathrm{a}$ \\
\hline
\end{tabular}

Means with different letters are significantly different (Fisher's LSD, $P=0.05$ ). 


\subsection{Organoleptic quality}

The highest overall appearance scores were obtained by 1-MCP-treated apples harvested on 30th September and 7th October (table III), which is mainly due to inhibition of superficial scald and retention of green peel colour [19]. 1-MCP-treated fruits from harvest 1 developed severe scald, which made them very unattractive.

The strong positive influence of 1-MCP treatment was also observed in the crispiness and juiciness values, regardless of harvest time. This is due to retention of fruit firmness, which is one of the most evident effects 1-MCP has in apples. Harvest time had a strong effect on crispiness and juiciness of untreated fruits, showing a decline in scores when the harvest time was later. A similar result was found in Mondial Gala apples [24].

Scores for mealiness showed that untreated fruits exhibited a remarkable increase in this disorder, as previously reported [25]. The results show that both 1-MCP and optimal harvest time have a positive effect on the absence of this disorder.

The highest taste score was obtained for 1-MCP-treated fruits harvested on 7th October, but other 1-MCP-treated fruits also had high scores. Akbudak et al. explained this situation as a consequence of retention of titratable acidity and inhibition of the reduc- tion of sugars due to the decline in respiration rate caused by 1-MCP [19].

Regarding aroma, the panellists did not find significant differences between 1-MCPtreated and untreated fruits, which can partially be explained by the absence of distinctive taste of Granny Smith apples [26]. Only untreated fruits harvested on 7th October were scored with significantly lower values due to off-odours of overripe fruits.

\section{Conclusion}

Combining 1-MCP and the optimal harvest date can effectively reduce severity of superficial scald in Granny Smith, a cultivar very susceptible to this physiological disorder. Although 1-MCP did not prove to efficiently prevent scald appearance during shelf life on early-harvested fruits, treatment of apples harvested one and two weeks later were able to suppress scald appearance. 1-MCP clearly minimised loss of firmness and titratable acidity and did not have a significant effect on total soluble solids content. Organoleptic quality of 1-MCP-treated apples was also at a high level. Fruits that were harvested at advanced maturity stages were of satisfactory quality only if they were treated with 1-MCP. Our results show that 1-MCP treatments of late-harvested Granny Smith apples could offer satisfactory results

Table III.

Effect of 1-MCP applied at the time of fruit harvest and of three different harvest dates on organoleptic quality parameters of Granny Smith apples stored at $1^{\circ} \mathrm{C}$ for 6 months followed by a shelf-life period of 7 days at $(21 \pm 1){ }^{\circ} \mathrm{C}$. Evaluations of each parameter were conducted by five academic panellists. Scores were: bad (1-3), good (4-6) and very good (7-9) (Serbia, 2009).

\begin{tabular}{lccccccc} 
Harvest date & Treatment & Overall appearance & Crispiness & Juiciness & Mealiness & Taste & Aroma \\
\hline 23 September & Control & $1.0 \mathrm{c}$ & $6.2 \mathrm{ab}$ & $6.0 \mathrm{ab}$ & $6.0 \mathrm{bc}$ & $5.8 \mathrm{~b}$ & $5.6 \mathrm{a}$ \\
& $1-\mathrm{MCP}$ & $3.0 \mathrm{~b}$ & $6.8 \mathrm{ab}$ & $6.6 \mathrm{ab}$ & $7.6 \mathrm{ab}$ & $6.6 \mathrm{ab}$ & $6.2 \mathrm{a}$ \\
30 September & Control & $3.2 \mathrm{~b}$ & $5.8 \mathrm{~b}$ & $5.4 \mathrm{~b}$ & $5.6 \mathrm{c}$ & $5.6 \mathrm{~b}$ & $5.6 \mathrm{a}$ \\
(commercial harvest date) & $1-\mathrm{MCP}$ & $7.2 \mathrm{a}$ & $7.8 \mathrm{a}$ & $8.0 \mathrm{a}$ & $8.0 \mathrm{a}$ & $6.8 \mathrm{ab}$ & $6.4 \mathrm{a}$ \\
07 October & Control & $2.6 \mathrm{~b}$ & $1.6 \mathrm{c}$ & $2.2 \mathrm{c}$ & $1.8 \mathrm{~d}$ & $2.4 \mathrm{c}$ & $1.8 \mathrm{~b}$ \\
& $1-\mathrm{MCP}$ & $6.6 \mathrm{a}$ & $7.2 \mathrm{ab}$ & $7.0 \mathrm{ab}$ & $7.2 \mathrm{abc}$ & $7.8 \mathrm{a}$ & $6.2 \mathrm{a}$
\end{tabular}

Means with different letters are significantly different (Fisher's LSD, $P=0.05$ ). 
for long-term air storage considering both absence of superficial scald and retention of fruit quality.

\section{Acknowledgements}

We thank Rohm and Haas Italia, Agrofresh Inc., Mozzate, Italy, for the support of this research.

\section{References}

[1] Folchi A., Pratella G.C., Gregori R., Relationship between $\mathrm{O}_{2}$ levels, 1-methylcyclopropene (1-MCP), conjugated trienes (CTs) and superficial scald in 'Granny Smith' apples, Acta Hortic. 682 (2005) 2063-2068.

[2] Rowan D.D., Hunt M.B., Fielder S., Norris J., Sherburn M.S., Conjugated triene oxidation products of $\alpha$-farnesene induce symptoms of superficial scald on stored apples, J. Agric. Food Chem. 49 (2001) 2780-2787.

[3] Wang Z., Dilley D.R., Initial low oxygen stress (ILOS) controls scald of apples without using postharvest chemical treatments, Acta Hortic. 553 (2001) 261-266.

[4] Jemric T., Lurie S., Dumija Lj., Pavicic N., Hribar J., Heat treatment and harvest date interact in their effect on superficial scald of 'Granny Smith' apple, Sci. Hortic. 107 (2006) 155-163.

[5] Echeverría G., Fuentes T., Graell J., Lara I, López M.L., Aroma volatile compounds of 'Fuji' apples in relation to harvest date and cold storage technology. A comparison of two seasons, Postharvest Biol. Technol. 32 (2004) 29-44.

[6] Vielma M., Matta F., Silva J., Optimal harvest time of various apple cultivars grown in Northern Mississippi, J. Am. Pomol. Soc. 62 (2008) 13-21.

[7] Watkins C., Nock J., Whitaker B., Responses of early, mid and late season apple cultivars to postharvest application of 1-methylcyclopropene (1-MCP) under air and controlled atmosphere storage conditions, Postharvest Biol. Technol. 19 (2000) 17-32.

[8] Zanella A., Control of apple superficial scald and ripening - a comparison between 1methylcyclopropene and diphenylamine postharvest treatments, initial low oxygen stress and ultra low oxygen storage, Postharvest Biol. Technol. 27 (2003) 69-78.

[9] Jung S.K., Watkins C., Superficial scald control after delayed treatment of apple fruit with diphenylamine (DPA) and 1-methylcyclopropene (1-MCP), Postharvest Biol. Technol. 50 (2008) 45-52.

[10] Argenta L.C., Fan X.F., Mattheis J.P., Factors affecting efficacy of 1-MCP to maintain quality of apples fruit after storage, Acta Hortic. 682 (2005) 1249-1257.

[11] Coureau C., Westercamp P., Mathieu-Hurtiger V., Le 1-MCP ou 'SmartFresh ${ }^{T M}$ '. Un outil de maintien de la qualité, Infos-Ctifl 213 (2005) 42-46.

[12] Bai J., Baldwin E., Goodner K., Mattheis J., Brecht J., Response of four apple cultivars to 1-methylcyclopropene treatment and controlled atmosphere storage, HortScience 40 (2005) 1534-1538.

[13] Siegrist J.-P., Gasser, F., Recommandations 2008-2009 aux entrepositaires de fruits et legumes, Rev. Suisse Vitic. Arboric. Hortic. 40 (2008) 303-307.

[14] Peirs A., Scheerlinck N., Berna Perez A., Jancsók P., Nicolaï B.M., Uncertainty analysis and modelling of the starch index during apple fruit maturation, Postharvest Biol. Technol. 26 (2002) 199-207.

[15] Bauchot A.D., John P., Soria Y., Recasens I., Carbon dioxide, oxygen, and ethylene changes in relation to the development of scald in granny smith apples after cold storage, J. Agric. Food Chem. 43 (1995) 30073011.

[16] Fan X., Mattheis J.P., Blankenship S., Development of apple superficial scald, soft scald, core flush, and greasiness is reduced by MCP, J. Agric. Food Chem. 47 (1999) 30633068.

[17] Diamantidis Gr., Thomai T., Genitsariotis M., Nanos G., Bolla N., Sfakiotakis E., Scald susceptibility and biochemical/physiological changes in respect to low preharvest temperature in 'Starking Delicious' apple fruit, Sci. Hortic. 92 (2002) 361-366.

[18] Gvozdenović D., Magazin N., Influence of harvesting date, treatment and storage conditions on scalde appearance on 'Granny Smith' from sandy soil, Acta Hortic. 682 (2005) 2091-2094.

[19] Akbudak B., Ozer M.H., Erturk U., Cavusoglu S., Response of 1-methylcyclopropene 
treated "Granny Smith" apple fruit to air and controlled atmosphere storage conditions, J. Food Quality 32 (2009) 18-33.

[20] Harker F., Maindonald J., Murray S., Gunson F., Hallett I., Walker S., Sensory interpretation of instrumental measurements. 1: Texture of apple fruit, Postharvest Biol. Technol. 24 (2002) 225-239.

[21] Ferrandino A., Thedy L., Duverney C., Di Stefano R., Aroma evaluation of apple fruits from different Italian growing locations, Acta Hortic. 553 (2001) 229-232.

[22] Rupasinghe H.P.V., Murr D.P., Paliyatli G., Skog L., Inhibitory effect of 1-MCP on ripening and superficial scald development in "McIntosh" and "Delicious" apples, J. Hortic. Sci. Biotechnol. 75 (2000) 271-276.
[23] Johnson D., Improvement in the storage quality of apples in the UK by the use of 1-MCP (SmartFresh), Acta Hortic. 59 (2003) 39-47.

[24] Neri F., Gualanduzzi S., Brigati S., Effects of harvest maturity on quality, physiological and pathological disorders during storage of 'Gala' apples, Acta Hortic. 682 (2005) 20692077.

[25] Soria Y., Recasens I., Labarta L., Larrigaudière C., Barreiro P., Effects of 1-methylcyclopropene treatments on mealiness of Early Red One apples, Acta Hortic. 682 (2005) 639-645.

[26] Morgan J., Richards A., The new book of apples, Ebury Press, London, U.K., 2002.

\section{Calidad de las manzanas Granny Smith cosechadas en fechas diferentes y tratadas con 1-MCP.}

Resumen - Introducción. Desde un punto de vista económico, la escaldadura superficial constituye uno de los factores de depreciación más graves para las manzanas cosechadas. La elección de un periodo óptimo de cosecha, así como la aplicación de un tratamiento con 1MCP permiten reducir notablemente el riesgo de aparición de esta escaldadura, así como conservar la calidad de las manzanas almacenadas en atmósfera normal. Material y métodos. Se trataron con 1-MCP (SmartFresh ${ }^{\mathrm{TM}}$ ) frutos cosechados en tres fechas diferentes (23 y 30 de septiembre y 7 de octubre de 2008) inmediatamente tras su cosecha, se almacenaron en atmósfera normal a $(1 \pm 0,5)^{\circ} \mathrm{C}$ durante 180 días. A continuación se dejaron durante 7 días a (21 \pm 1) ${ }^{\circ} \mathrm{C}$. En los días 1 y 7 de almacenamiento se evaluaron la gravedad de la escaldadura superficial, la firmeza de los frutos, su contenido total en sólidos solubles y su acidez valorable. Se evaluó también su calidad organoléptica al final del periodo de conservación. Resultados. El tratamiento con 1-MCP permitió controlar la escaldadura superficial antes y después del periodo de 7 días a $(21 \pm 1)^{\circ} \mathrm{C}$ para los frutos cosechados en las dos últimas fechas. Durante dicho periodo, la escaldadura fue más marcada para los frutos de la primera cosecha, independientemente de si fueron o no tratados con 1-MCP (3,6 y 2,3, respectivamente). La aplicación de 1-MCP así como una cosecha precoz tuvieron un efecto positivo en el mantenimiento de la firmeza y en el contenido de acidez valorable durante el almacenamiento. El contenido total en sólidos solubles no se vio afectado por el tratamiento con 1-MCP. La combinación de un tratamiento con 1-MCP junto con una cosecha a mediados o a final de temporada ofrecieron mejores resultados de evaluación de la calidad organoléptica de las manzanas almacenadas. Conclusión. Nuestros resultados muestran que los tratamientos con 1-MCP aplicados en las últimas fechas de cosecha podrían ofrecer resultados satisfactorios para el almacenamiento al aire, a largo plazo, de las manzanas "Granny Smith" dado tanto a la ausencia de la escaldadura superficial como al mantenimiento de la calidad de los frutos.

Serbia / Malus (frutas) / almacenamiento atmósfera controlada / enfermedades postcosecha / escaldadura / elección de la época / fecha de recolección / aptitud para la conservación 